Volume 3, Issue 1 (Winter 2011)

\title{
Albrecht Dürer's Peasant Engravings: A Different Laocoön, or the Birth of Aesthetic Subversion in the Spirit of the Reformation
}

Jürgen Müller

Recommended Citation:

Jürgen Müller, “Albrecht Dürer's Peasant Engravings: A Different Laocoön, or the Birth of Aesthetic Subversion in the Spirit of the Reformation," JHNA 3:1 (Winter 2011), DOI: 10.5092/ jhna.2011.3.1.2

Available at https://jhna.org/articles/albrecht-durer-peasant-engravings-different-laocon-birth-aesthetic-subversion-spirit-reformation/

Published by Historians of Netherlandish Art: https://hnanews.org/

Republication Guidelines: https://jhna.org/republication-guidelines/

Notes: This PDF is provided for reference purposes only and may not contain all the functionality or features of the original, online publication. This is a revised PDF that may contain different page numbers from the previous version. Use electronic searching to locate passages. This PDF provides paragraph numbers as well as page numbers for citation purposes.

ISSN: $1949-9833$ 


\section{ALBRECHT DÜRER'S PEASANT ENGRAVINGS: A DIFFERENT LAOCOÖN, OR THE BIRTH OF THE AESTHETIC SUBVERSION IN THE SPIRIT OF THE REFORMATION}

\section{Jürgen Müller}

This article addresses the genesis and reception of three engravings representing peasants made by Albrecht Dürer between the years 1514 and 1519. These images have been interpreted as social commentary or low-brow farce; I argue their importance is art theoretical. In my view, they are the result of Dürer's 1505-6 visit to Venice, where Italian artists derided his ability to work in a classical idiom. In response, I argue, Dürer developed a method of imitation that I call "inverse citation," which veils a famous antique model in the guise of a boorish peasant. Following Luther's rebellion against the Church, northern artists took up this technique with more polemical aims. 10.5092/jhna.2011.3.1.2

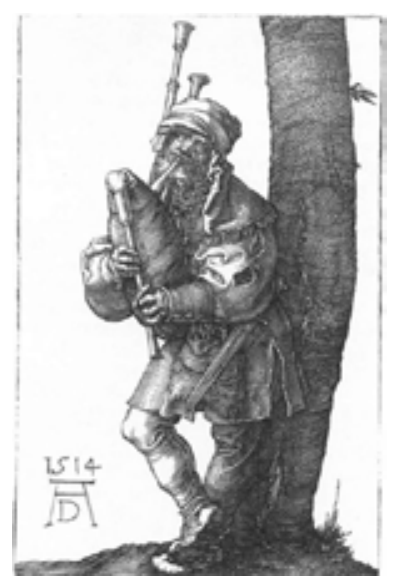

Fig. 1 Albrecht Dürer, Bagpiper, 1514, engraving, $11.5 \times 7.4 \mathrm{~cm}$. Metropolitan Museum of Art, New York (artwork in the public domain).

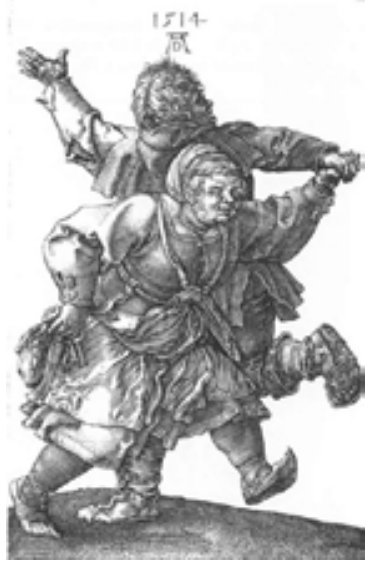

Fig. 2 Albrecht Dürer, Peasant Couple Dancing, 1514, engraving, $11.7 \times 7.5 \mathrm{~cm}$. Metropolitan Museum of Art, New York (artwork in the public domain).

\section{Dürer's Peasant Pictures as a New Beginning} n 1514, Albrecht Dürer created two copperplate engravings that must be conceived as counterparts. One presents a bagpiper playing his pipe (fig. 1), while the other shows a peasant couple dancing (fig. 2). The corresponding subjects and similar compositions of the engravings, with the placement of the figures on a dark, narrow strip in the foreground, render them a pair. The background of both prints is blank, emphasizing the artist's monogram and giving the figures a sculptural quality. 
These are by no means the first engravings portraying peasants in the Nuremberg artist's oeuvre, but never before have peasants appeared so monumental. This is achieved through intelligent compositional structure; because Dürer refrains from portraying the surroundings, the figures dominate the pictorial space. In comparison to his 1497 representation of rustic figures, which depicts three market-goers casually engaged in conversation, the poses of the figures in the 1514 engravings appear studied. ${ }^{1}$ The bagpiper, for instance, strikes up his tune with his limbs arranged in a rather deliberate configuration that gives him a melancholy air; he leans against a tree with his feet crossed and his head tilted in concentration.

Another striking aspect of the images is the artist's meticulous observation of detail. The contour of the bagpiper's smooth leather shoe clearly shows the toes of the right foot, a detail repeated in the foot of the dancer. The flowing lines of the creases in the woman's apron seem to echo the direction of her spinning movement. The high-flying, wild hair of the male dancer, with his open mouth represented in profile, expresses unbounded merriment. Everything is depicted with the utmost precision and awareness of composition; in this scrupulous attention, we can perceive the ambition of the artist, who in the same year was to produce his most mysterious work, Melancolia I.

4 Art historians have interpreted these works in a number of ways. There has been the attempt by Marxist art historians to detect the artist's sympathy for the peasant class in the engravings, an interpretation which can be justified to some extent by the monumental impression made by the figures. ${ }^{2}$ In Bauernsatiren, his comprehensive description of peasant images, Hans-Joachim Raupp undermines this reading, however, by convincingly outlining what he sees as a set of tropes characterize of the peasant genre. ${ }^{3}$ For the most part, Raupp's discussion does not take into account the artistic ambitions of individual works like Dürer's. Keith Moxey and Alison Stewart have also investigated peasant images as a genre in sixteenth-century German prints. ${ }^{4}$ Whereas Moxey sees the primary theme of such works as being mockery in the service of social differentiation (city-dwellers laughing at peasants), and Stewart argues that prints representing peasants partook in a humanist as well as a low-brow, humorous discourse, both scholars interpret the images in terms of their social context. My own approach stays close to Dürer's images and reads them as an element of his larger art theoretical program. It is important to note that two peasant pictures were created at the same time as the Meisterstiche, the master engravings; this was a period of exploration in which Dürer used the medium of print to meditate on what art was capable of. As Erwin Panofsky makes clear in his studies on the artist, Dürer's contact with Italian art and Italian art theory played a large role in these meditations. ${ }^{5}$ However, in contrast to Panofksy, I do not see Dürer's relationship to Italian art as affirmative. In the following, I will argue that the two compositions were the result of Dürer's second journey to Italy in the years 1505-6 and contain a critical comment on his experiences there. ${ }^{6}$

\section{Dürer's Rivalry with Italy}

5 We have long been accustomed to citing Albrecht Dürer as the first northern European artist to devote his attention intensively to Italian and antique models. ${ }^{7}$ The journeys to Venice have been described many times, and their consequences neatly analysed. ${ }^{8}$ It is clear that the journeys to Italy brought a boost of innovation to the Nuremberg artist's work, but the analysis of how he dealt with such influences has been far too indiscriminate, treating the artist as if he were a sort of 
vessel, empty at his arrival and full at his departure. We only have to read his letters of that period to perceive otherwise.

In a letter to his friend the humanist Willibald Pirckheimer, from Venice, dated February 7, 1506, Dürer writes that he no longer likes those works that appealed to him during his first stay in Italy. More interestingly, for the first time he reports on the dislike his Italian colleagues felt for him; he feels well-nigh persecuted by them. In one passage, he accuses envious colleagues of theft: "I do have many enemies among them [i.e., the Italian painters] who copy my works in the churches or wherever they may get them; in order to criticise me afterwards and to claim that my work does not fully comply with classical art and therefore cannot please."

Some of Dürer's Italian colleagues envied him because he had become a serious rival, evidence of his development since his first stay in Italy in 1495. Another letter to Pirckheimer, dated September 8,1506 , demonstrates that Dürer felt himself under pressure from his Italian critics. Triumphantly, he writes: "I also silenced all the painters who said that I was good at engraving, but in painting I didn't know how to handle the colours. Now everyone says they have never before seen more beautiful colours." 10

8 Rivalry, as seen from the letters, does not have to be unconstructive. As Leonardo pointed out, one will envy artists who are more praised than oneself, but this can function as a positive goad to an artist to outstrip his competitors. Competition, in the sense of aemulatio, is one of the main driving forces of artistic progress. ${ }^{11}$ In my opinion, Dürer's peasant pictures are his attempt to break the cycle of competition and rivalry that is described in his letters from Venice. Instead of a display of bravado, he responds with understatement - from the point of view of Italian artists, who valued antique models, there can hardly be a less spectacular topic than boorish peasants.

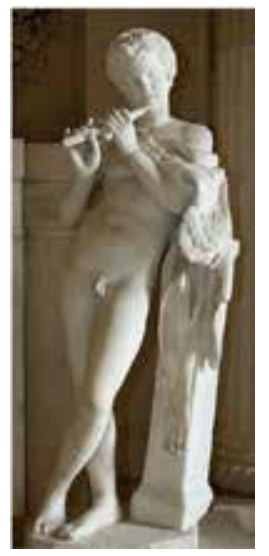

Fig. 3 Roman copy after Praxiteles, Piping Faun, second century C.E., marble, h. $132 \mathrm{~cm}$. Collection Borghese, Rome

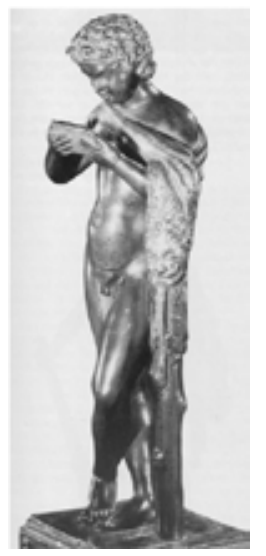

Fig. 4 Jacopo Alari-Bonacolsi, called Antico, Young Hercules Reading, ca. 1500, bronze, h. $22.9 \mathrm{~cm}$. Private Collection

If we look closely, we can see that Dürer allows himself an ironic joke in his copperplate engravings. In examining the Bagpiper, we are struck at the peculiarity - anatomically speaking - of the foot set on the ground so that it allows a glimpse of the sole. The right leg seems strangely twisted. The skewed position of the head also appears awkward in view of the strenuous task of the bagpiper. However, we can understand the clumsiness of his posture if we detect the model the artist is alluding to. He cites no less a work than the piping Faun of Praxiteles (fig. 3), which has come down to us in various copies and variants. A sculpture by Antico from around 1500 (fig. 4) portraying the young Hercules reading shows how highly valued this particular image was and 
how much critical attention it received from contemporary artists. ${ }^{12}$ The Italian artist reproduces the static motif identically but replaces the pipe with a book.

Unlike his Italian predecessor, Dürer made a noticeable effort to hide the model, a fact that clearly shows his ironic intention. ${ }^{13}$ Praxiteles's work is the very epitome of artistic grace, an equal to the Boy Extracting a Thorn. The motif of the crossed feet is particularly striking, but the boy's elegant posture is also eye-catching. The faun is completely lost in his music. He seems to be making music and at the same time sent into raptures by his own music - a touching picture of self-forgetfulness. In Dürer's boorish musician figure, this beauty is veiled by a kind of a Socratean mask. In the Symposium, Socrates is compared to a hollow statue of Silenus, which is ugly on the outside but contains beautiful, golden statues of the gods on the inside. ${ }^{14}$ Likewise, Dürer's citation is only revealed to those who know how to look "inside" it. ${ }^{15}$

11 In light of the criticism that Dürer faced in Venice, his intention becomes clear. He chooses a typically German, i.e., inelegant, topic that invites the criticism of beholders versed in the Italo-antique tradition. Yet, the critic who assumes that the crudeness and simplicity of the subject equates to crude execution reveals his own ignorance. The way Dürer deliberately botches the detail of the elegantly crossed foot seems almost coquettish. This artist, after all, was the creator of the Adam and Eve (1504); he was certainly capable of portraying the ideal human form according to the antique canon. In the Bagpiper, the artist pulls back. It is as if Dürer gives us a glimpse of the peasant's broken sole because he could not cope with the sight of so much gracefulness.

\section{Inverse Citation}

12 In his peasant engravings, Dürer invents nothing less than a new iconographic mode of art: the inverse citation. This mode aims first of all to unmask the "ideological" critics who esteem national considerations more highly than artistic ones. In doing so, he follows the advice of Quintilian in The Orator's Education. The latter recommends the practice of dissimulatio in the sense of passive irony, according to which the speaker pretends to be ignorant but uses this feigned naïvete to tempt the opponent into feeling superior. ${ }^{16}$ This applies to the copperplate engraving in that the motif of the rustic musicians is negatively connoted. The contemporary viewer may have been reminded of the fifty-fourth chapter of Sebastian Brandt's Ship of Fools (fig. 5), which presents

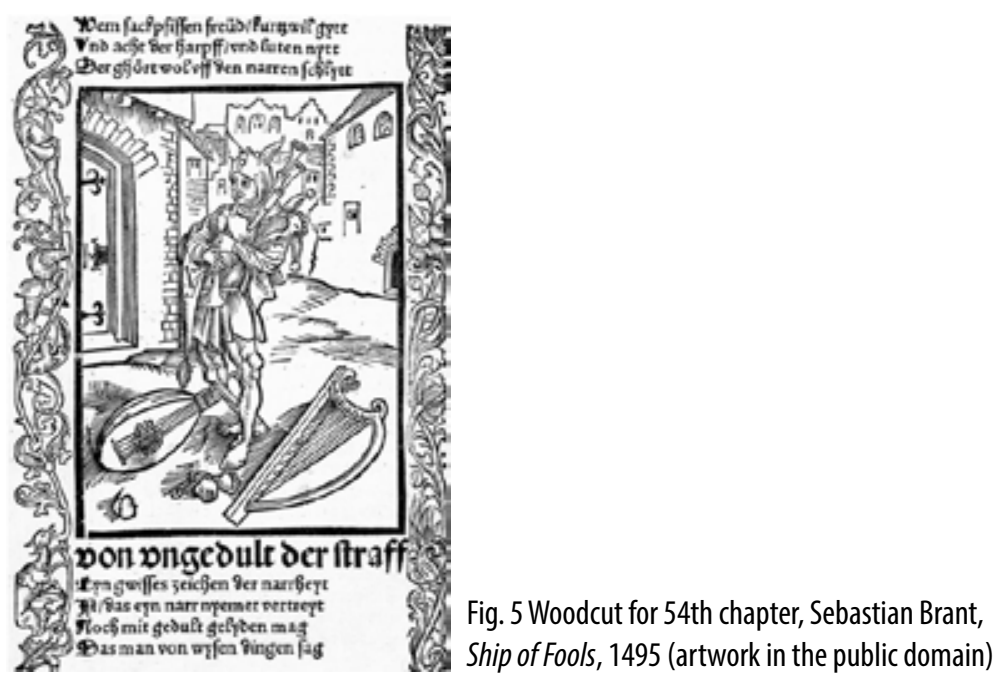


the bagpiper as a symbol of foolishness and obstinacy. The instrument resembles the male sexual organ and signals man's animal instincts, which seem to have become the bagpiper's one and only concern. The lute and the harp, which lie on the ground, stand for the intellectual-spiritual dimension of music, as we are informed by the doggerel verses in the Ship of Fools: "Eyn sackpfiff ist des narren spil / Deer harppfen achtet er nit vil / Keyn gu(o)t dem narren in der welt / Baß dann syn kolb/, und pfiff gefelt." 17

13 The Peasant Dance has a similarly ironic pictorial structure. Dürer quite evidently concentrates on the boorish character of the dancers, who, although completely lacking in grace, are in very high spirits; the woman's stocky build and the wild gestures are exploited as a source of comedy. A more critical examination reveals another level of wit. Dürer has included an optical irritation in his rendering: the peasants' feet and calves are depicted in such a way that it is difficult at first sight to attribute each leg to its proper owner. The artist's visual humour consists in creating the impression that the peasant woman has no right leg - according to the laws of physics, she should actually fall over. The artist intensifies this notion by staging the pictorial narrative along an ascending diagonal that starts with the foot of the peasant woman and continues toward her outstretched arm.

14 In this engraving, the cited work is nothing less than the Laocoön group (fig. 6), deployed once again with an ironic intention. ${ }^{18}$ The inversion of the model is comic and must be seen yet again in the context of an insinuated ignorance of antique culture. The peasant woman is literally and figuratively a mirror image of the statue. With her diagonally outstretched arms, bent legs and plump, womanly body, she both echoes and inverts the heroic figure of the priest of Poseidon. Note as well the male dancer with wildly flying locks who has opened his mouth wide to shout, reproducing another view of the famous sculpture. It is clear that Dürer studied the Laocoön group thoroughly, not only in order to paraphrase its form but also to reproduce it in a conventional way. This latter manner of quotation is demonstrated in his sketches for the Fugger Epitaph (fig. 7) from 1510, which similarly quotes the iconic, diagonally outstretched arms of the priest in the original. ${ }^{19}$ Recognizing in the form of the dancing peasant woman a distortion of the priest figure from the Laocoön group requires an eye that is as trained as it is erudite. Dürer exercises great skill in concealing his "citation," while at the same time cleverly pointing to it. In the inverse citation, showing and concealing overlap. ${ }^{20}$

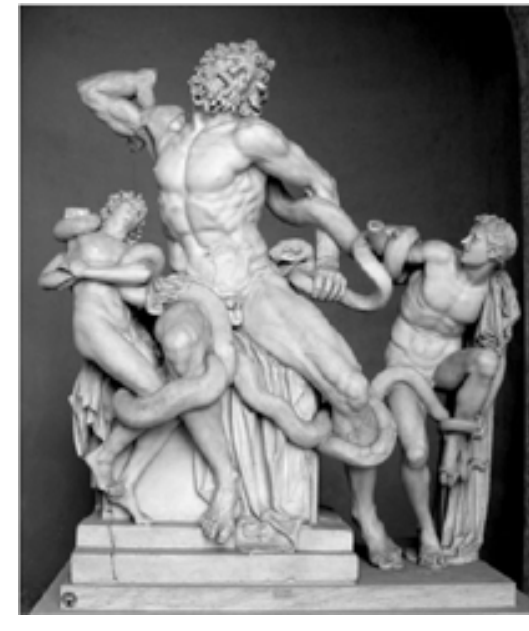

Fig. 6 Laocoön Group, mid-first century C.E., marble, h. $242 \mathrm{~cm}$. Vatican Collection, Rome

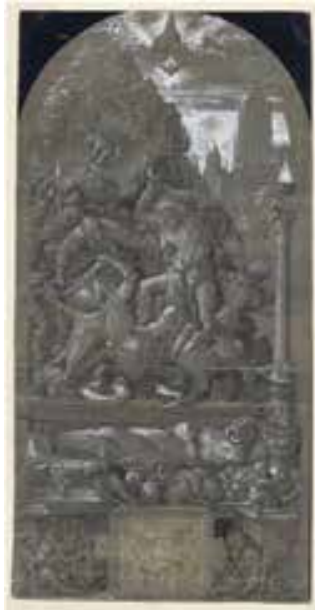

Fig. 7 Albrecht Dürer, Samson Slaying the Philistines (sketches for the Georg Fugger Epitaph), 1510, gray wash and brush on colored paper, 32.1 x $15.6 \mathrm{~cm}$. Kupferstichkabinett, Staatliche Museen zu Berlin 
15 The more subtly an artist uses an allusion, the more he is required to give indirect hints that confirm the recipient in recognizing the citation - thus Dürer's invention of the yelling dancer with his arm swung upwards, who reproduces another view of the central figure. A double movement is taking place in Dürer's inverse-ironic citation. The cited subject is transformed beyond recognition and must therefore be evoked through the adoption of significant motifs like the shout and the open mouth, high-flying hair and the lifted arm - all centrally connected with the figure of the priest. But like any ironic statement that deserves the designation, it is easier to overlook than recognize. The difficulty of such a procedure is obvious: if the artist hides the model too much, the reference cannot be detected, and if the model is too easily recognized, the reference runs the risk of being perceived as a parody.

16 The fact, however, that Dürer developed this ironic mode of art following the confrontation with his Italian critics must not lead us to think that he did so only out of wounded vanity. On the contrary, a serious art-theoretical context needs to be considered here. Dürer's peasant pictures mark the beginning of a new aesthetic potential in the visual arts - the potential for subversion. And as the Latin root of this word reminds us (sub means under), artistic standards and the degree to which they can be enforced are inseparable from each other. Culture has always been determined by questions of hegemony; in other words, the canon of antique works that includes the Laocoön owes its existence not to any objective criteria but rather to ability of the dominant civilization, that of Italy (or even of Rome), to impose its authority. Italian art theory followed the classical theory of types and - with regard to painting - is hierarchically structured. According to the hierarchy, the depiction of Christian or mythological historical subjects is the noblest task of the painter, who achieves a certain status with his choice of topic. ${ }^{21}$

17 Dürer made some critical remarks on this matter, writing in his theory of proportions: "But it must be noted that a gifted and trained artist is better able to show his genius and his skill by depicting a peasant figure and other simple motifs rather than executing important works of art." ${ }^{\prime 2}$ As the passage makes clear, artistic quality is not bound to themes and motifs but follows purely aesthetic criteria. This must also be taken into consideration in Dürer's choice of a small format and the less-valued print medium. For Dürer, medium could not, in and of itself, guarantee artistic pre-eminence.

\section{Dürer, Vellert, Holbein}

18 In July 1520, Dürer set out for the Low Countries, a journey thoroughly described for us in his travel diary. It is known for example that Dürer regularly met the Antwerp artist Dirck Vellert, whom he calls a glass painter and who in those years was dean of the Antwerp guild. ${ }^{23} \mathrm{He}$ met the Fleming for the first time in the autumn of 1520, when the latter provided Dürer with red pigment derived from bricks. On May 12of the following year, Vellert arranged a banquet for Dürer, to which many artists and prominent persons were invited, as Dürer briefly reports - at least he mentions a delicious meal and that he was treated with "great honour." ${ }^{4}$

19 Dürer produced his third copper engraving (fig. 8) dedicated to a peasant subject shortly before his journey to the Low Countries. The same size and format as the Dancing Peasants and the Bagpiper (all roughly $116 \times 73 \mathrm{~mm}$ ), the engraving of 1519 seems to have served on the journey as a 


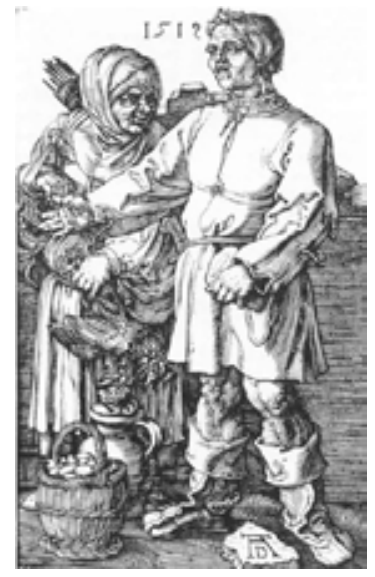

Fig. 8 Albrecht Dürer, Peasants at the Market, 1519, engraving, $11.6 \times 7.3$ $\mathrm{cm}$. Metropolitan Museum, New York

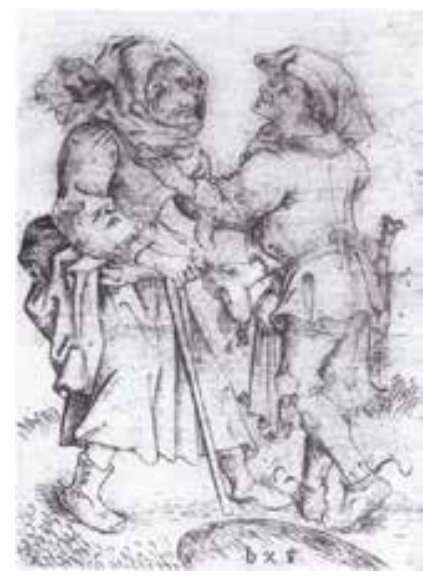

Fig. 9 Master BXG, Unequal Lovers, ca. 1480 , engraving, $8.3 \times 5.9 \mathrm{~cm}$. Bibliothèque nationale, Paris

gift for his hosts; he often mentions giving the "new peasant" as a gift. ${ }^{25}$ This time, however, the couple is not freestanding, but is positioned in front of a crumbling wall. The artist has painted the year between the heads of the couple and his monogram on a stone at their feet. The man, whose chubby cheeks and muscular build indicate that he is still young, stretches out his right arm; his purse is in his left hand, and he is about to say something. The meaning of the engraving is controversial, but it seems to me to allude to a sexual joke. The old woman holding two dead cocks in her left hand has made a sexual offer to the young man, who now anxiously holds his "money bag." Further, the jug and the egg basket have sexual connotations. The subtext of Dürer's picture is the theme of the unequal lovers; the brash old woman is juxtaposed in lewd contrast to a timid young man, who makes a gesture of rejection. ${ }^{26} \mathrm{~A}$ copper engraving with the monogram "bxg", dated 1480, demonstrates that such an erotic level was not unexpected in the peasant genre (fig. 9). It shows an old woman opening her beau's shirt while he touches her breast. ${ }^{27}$ This erotic behaviour is accompanied by a financial transaction, as the old woman hands over her purse to pay for the received caresses. ${ }^{28}$

20 Five years had passed between the first two peasant pictures and the making of Peasants at the Market, but it is apparent that the artist has endowed the third copper engraving with a cryptic ironic dimension as well. Dürer uses his technique of dissimulatio to analogize his peasant to a Roman soldier, for instance, those found on sarcophagi (fig. 10). Dürer evidently saw his peasant pictures as a series, all following the same ironic laws. The allusions made in these works are so tremendously complicated that they require the reciprocal interconnection of all three works of art.

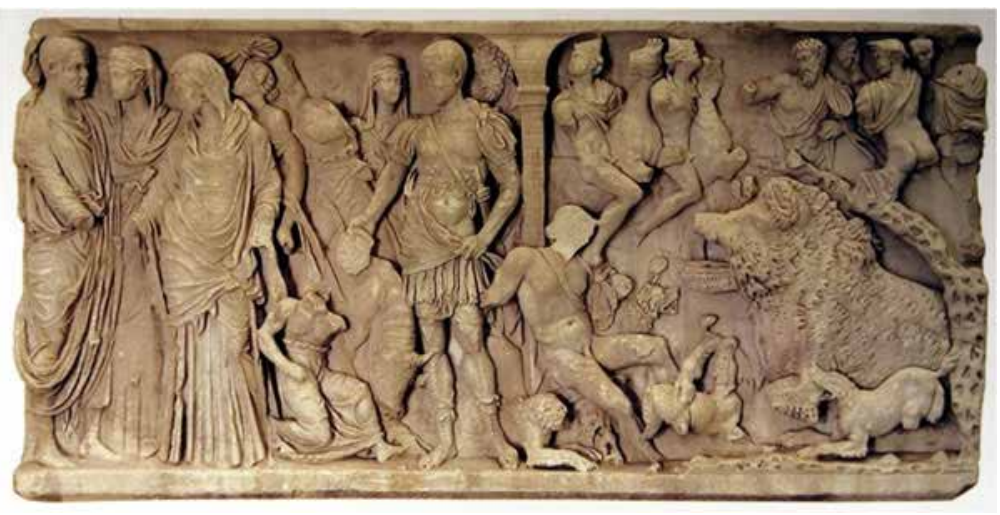

Fig. 10 Sarcophagus Rinuccini, second century C.E., marble, h. $212 \mathrm{~cm}$. Antikensammlung, Altes Museum, Staatliche Museen zu Berlin 
21 Who was then able to understand such sophistication? Dürer's anecdotes indicate that he was addressing his artist colleagues, but even without the art theoretical subtext, the copper engravings offer the beholder an aesthetically satisfying experience. The important point here is that solemn antique motifs are re-molded into humorous, genre-type scenes; gravity is concealed behind flippancy. Artists, particularly in the north, who had experienced the arrogance and condescension of their Italian colleagues as a thorn in their sides, must have appreciated such humour.

22 Unfortunately, we do not know the topic of conversation at the banquet arranged in Antwerp for Dürer by Dirk Vellert. Perhaps the Flemish artists asked him to talk about his journeys to Italy. Maybe they even asked him to tell them about the important works of art that he studied on the other side of the Alps. In any case, we can see how Dürer's ironic treatment of ancient models was received by his northern colleagues in the works of Vellert, who was active in Antwerp from 1511 to $1544 .^{29}$

23 Beginning in the early 1520s, immediately after Dürer's arrival in Antwerp, Vellert began to produce ironic images of the Laocoön. It is impossible to say if Vellert learned the technique from Dürer during his stay in the southern Low Countries, or if he discovered the visual humour of the Nuremberg artist on his own. Whatever the case may have been, we can judge the effect of Dürer's visit in two etchings by Vellert that take the Laocoön as their model. A portrayal of Bacchus (fig. 11) dates from 1522 and that of a bellowing drinker (fig. 12) from 1525. Once more, the etchings transpose the main motif of the antique sculptural group into a genre-type scene. The drunken Bacchus has to prop himself up so as not to lose his balance, while the drinker has already lost his composure. Intoxicated as he is, he calls out for more beer, his gaping mouth perverting the impression of noble suffering made by the open-mouthed priest. This image perverts the impression of noble suffering made by the open mouth of the priest into an image of vulgarity.

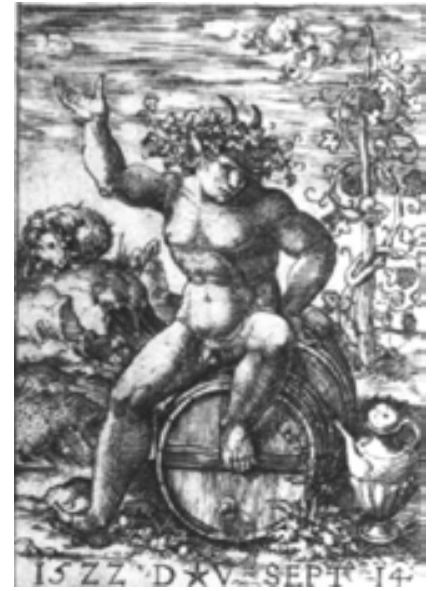

Fig. 11 Dirk Jacobsz. Vellert, Bacchus, 1522, engraving and etching, $7.2 \times 5.1 \mathrm{~cm}$. Print Room, Rijksmuseum, Amsterdam

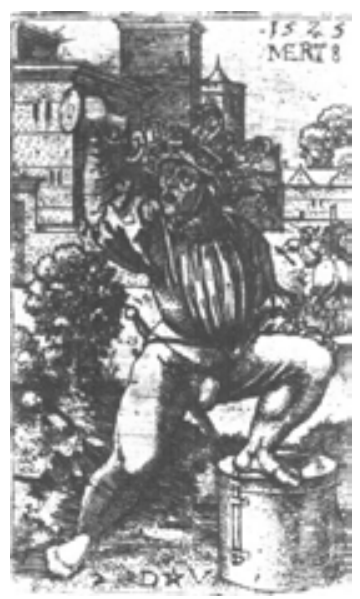

Fig. 12 Dirk Jacobsz. Vellert, The Drunken Drummer, 1525, engraving, $9.2 \times 5.8 \mathrm{~cm}$. Kupferstichkabinett, Staatliche Kunstsammlungen, Dresden

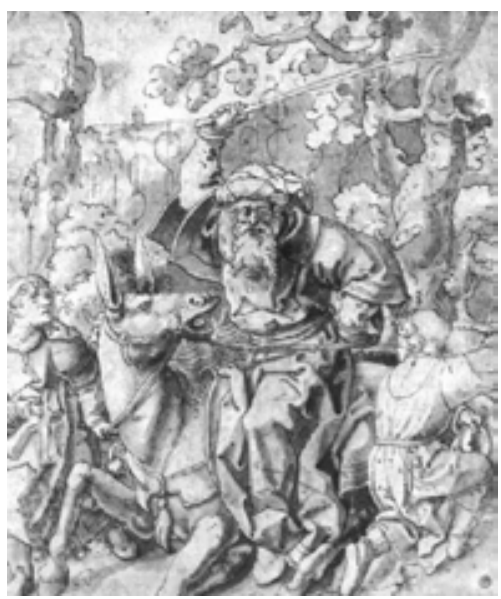

Fig. 13 Dirk Jacobsz. Vellert, Bileam and the Ass, ca. 1522, ink drawing, $19.4 \times 18.7 \mathrm{~cm}$. Herzog Anton Ulrich Museum, Braunschweig

24 Like Dürer before him, Vellert engaged in serious study of the sculptural group. This is proven by an undated drawing (fig. 13) showing Bileam and the she-ass. To the right and left of the falling prophet, his arms extended in the iconic Laocoön diagonal, we recognize two servants, an allusion 
to Laocoön's sons. The Antwerp artist demonstrates two things with his adaptations from antiquity. First, he manages to deploy the classical model within the context of the Bileam narrative while more or less upholding the iconographic meaning. ${ }^{30}$ The blinded ancient priest is changed into a (figuratively) blind prophet. Second, the artist reveals an ironic intention by turning the tragic (Laocoön's demise) into the ridiculous (Bileam's dispute with the donkey), filling an elevated form with comic content. Vellert's treatment of the Laocoön demonstrates that the inverse citation is an artistic exercise. The ability to so invert a model was apparently seen as proof of consummate artistic skill. ${ }^{31}$ Hans Holbein allows himself a similar jest in the "Imagines mortis" graphic series, where he constantly paraphrases motifs from the Laocoön group. ${ }^{32}$

25 Such a subversion of the Laocoön would not have been possible if its role as an aesthetic norm had not already been established, as it was in the Italian High Renaissance, whose artists relied on antiquity as a source. ${ }^{33}$ Subversion as an artistic practice is parasitical in that it cannot exist without a host. For the works of antiquity to have achieved the status of an aesthetic norm they had to be accessible, which became increasingly true during the pontificate of Julius II, who assembled an extraordinary collection of ancient works of art, began the rebuilding of St. Peter's Basilica, and employed the two most prominent artists of the sixteenth century, Raphael and Michelangelo. Besides St. Peter's, emblems of this grandiose art policy include the adornment of the Sistine Chapel by Michelangelo, Raphael's stanze, and the rediscovery of the Laocoön group in 1506 and its incorporation into the papal collections. ${ }^{34}$ In fact, the Laocoön became a sort of papal trade mark; Julius II exploited the rediscovery of the Hellenistic figural group, using it to confirm his predestination as pope. ${ }^{35}$

All of this was too much for northern European theologians of the time. Already resentful of his martial church policy, they felt Julius II's patronage was too pagan and ambitious for a pope. The pope's self-fashioning as a successor of the Roman emperors can be perceived in his enthusiasm for classical antiquity in literature and the visual arts, which he deployed as discernibly imperial gestures. ${ }^{36}$ The polemical dialogue of Erasmus, Julius Excluded from Heaven is a good illustration of this context. The tract, which first appeared in 1515 in Leiden, offers a damning portrait of the head of the Catholic Church. In Julius's conversation with Saint Peter, he reveals himself as an unchristian despot who cannot be helped and is therefore refused access to heaven.

27 Ulrich von Hutten was once thought to be the author of this papal satire, but stylistic comparisons add credence to the argument that Erasmus is its author. The tone of the dialogue is already evident at the beginning, when Peter is called to heaven's gate. Peter thinks that the Renaissance pope who asks for admittance is Caesar and calls him the "wicked pagan Julius," to which Julius replies "Ma di si!" ${ }^{77}$ When the apostle then refuses to open heaven's gate, Julius threatens him with excommunication. One farce follows another. It is easy to understand why the text appealed to Luther; according to the testimony of Bonifacius Amerbach, it was still being closely read in $1528 .^{38}$

28 On a practical level, the papal claim for cultural hegemony coincided with the circulation of printed graphic versions of the aforementioned works of art. The fame of these masterpieces spread rapidly in the north, and they were no less rapidly taken up and adapted by artists. As mentioned above, by 1510 Dürer had already used the central motif of the Laocoön group for 
his sketches of the Fugger Epitaph, four years after the rediscovery of the antique sculpture. In 1522, Hans Holbein made polemical use of this model for his portrayal of Luther as "Hercules germanicus" (fig. 14). ${ }^{39}$ Luther kills the Catholic Hydra while the pygmy-like pope is hanging on his nose. ${ }^{40}$

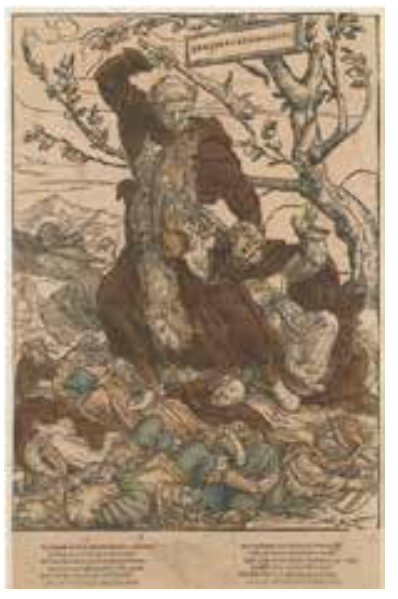

Fig. 14 Hans Holbein the Younger, Luther as "Hercules germanicus," 1522, woodcut, $34.5 \times 22.6 \mathrm{~cm}$ (From Heinrich Brennwald and Johannes Stumpf, Schweizer Chronik, Ms. A 2, before p. 150). Zentralbibliothek, Zürich

\section{Inverse Citations in the Art of the Reformation}

For Dürer, the issue was restricted to an artistic competition with Italy, but for following generations of northern European artists this conflict was exacerbated by the Reformation. ${ }^{41}$ From the early 1520s onward, what mattered was the emancipation of German art, the fight for equality with ancient and Italian models. In the year 1520, Luther published To the Christian Nobility of the German Nation Concerning the Reform of the Christian Estate. With this text he makes a definitive break with the Catholic Church by identifying the pope with the Antichrist. After having criticized letters of indulgence, bulls, confessional letters, "butter-letters," and other confessionalia, Luther wrote the following passage in his treatise: "I shall also say nothing at present of how this indulgence money has been applied. Another time I shall inquire about that, for Campoflore and Belvedere and certain other places are very much aware of it." ${ }^{2}$ The mention of the Cortile del Belvedere is a metonymic allusion to the sculptures erected there. The message is clear: the money of the German Christian finances the expensive art collecting and building policies of the pope. The fact that the Laocoön was politically exploited in order to show the cultural superiority of the papacy did not escape attention in the north und provoked strong objection. ${ }^{43}$ Seen from a reformist point of view, the Laocoön was a Catholic showpiece that virtually asked for mockery.

30 Finally, I wish to underline the modernity of the sixteenth century, which is revealed in the potential of nonequivalent aesthetics. ${ }^{44}$ Beginning with pagan antiquity, the aesthetic experience is understood to be based on a harmony between inside and outside. Outer beauty and inner virtue refer to each other. But this changes within the framework of Christian-reformist poetics. When inside and the outside diverge, when their relation is perceived as a conflict, nonequivalence determines the aesthetic experience. In such an aesthetics, the visible is in a way denounced, the actual step of perception leads beyond the visible and must be performed mentally. It is the special achievement of ironic art to allow form and content to diverge. Form is not imagined as a vessel of a fixed content, but the reversal that occurs with its recognition sets free a particular semantic potential. 


\section{Acknowledgements}

This article was translated from German by Ulrike Schenk. I would like to thank the following people for their help in preparing the English version for publication: Jessica Buskirk, Kerstin Küster, Wolf Seiter, and Alexandra Schellenberg. I would also like to thank the JHNA readers for their helpful comments. This article lays out the themes of a research project that I am leading, which is entitled "The Subversive Image" and is part of the Collaborative Research Centre 804 (SFB 804) at the Technical University Dresden, funded by the Deutsche Forschungsgemeinschaft. I would like to thank SFB 804 and the DFG for their support.

Jürgen Müller is Professor of Art History at the Technical University Dresden. He has taught at several universities in Germany and France. He organized exhibitions at the Hamburger Kunsthalle on the graphic works of Bruegel and Goltzius in addition to a large exhibition on German soccer. His main field of interest is the northern European art of the early modern period; he has published widely on Dürer, Holbein, Bruegel and Rembrandt, including his books Concordia Pragensis. Karel van Manders Kunsttheorie im Schilder-Boeck (1993) and Das Paradox als Bildform: Studien zur Ikonologie Pieter Bruegels d. Ä. (1999). His other field of interest is the history of photography and film, and he is the editor of a popular series published by Taschen on the history of movies.

\section{List of Illustrations}

Fig. 1 Albrecht Dürer, Bagpiper, 1514, engraving, 11.5 x $7.4 \mathrm{~cm}$. Metropolitan Museum of Art, New York (artwork in the public domain).

Fig. 2 Albrecht Dürer, Peasant Couple Dancing, 1514, engraving, 11.7 x 7.5 cm. Metropolitan Museum of Art, New York (artwork in the public domain).

Fig. 3 Roman copy after Praxiteles, Piping Faun, second century C.E., marble, h. 132 cm. Collection Borghese, Rome (artwork in the public domain).

Fig. 4 Jacopo Alari-Bonacolsi, called Antico, Young Hercules Reading, ca. 1500, bronze, h. 22.9 cm. Private Collection (artwork in the public domain).

Fig. 5 Woodcut for 54th chapter, Sebastian Brant, Ship of Fools, 1495 (artwork in the public domain).

Fig. 6 Laocoön Group, mid-first century C.E., marble, h. 242 cm. Vatican Collection, Rome (artwork in public domain).

Fig. 7 Albrecht Dürer, Samson Slaying the Philistines (sketches for the Georg Fugger Epitaph), 1510 , gray wash and brush on colored paper, 32.1 x $15.6 \mathrm{~cm}$. Kupferstichkabinett, Staatliche Museen zu Berlin (artwork in the public domain).

Fig. 8 Albrecht Dürer, Peasants at the Market, 1519, engraving, 11.6 x $7.3 \mathrm{~cm}$. Metropolitan Museum, New York (artwork in the public domain). 
Fig. 9 Master bxg, Unequal Lovers, ca. 1480, engraving, 8.3 x $5.9 \mathrm{~cm}$. Bibliothèque nationale, Paris (artwork in the public domain).

Fig. 10 Sarcophagus Rinuccini, second century C.E., marble, h. 212 cm. Antikensammlung, Altes Museum, Staatliche Museen zu Berlin, (artwork in the public domain).

Fig. 11 Dirk Jacobsz. Vellert, Bacchus, 1522, engraving and etching, 7.2 x $5.1 \mathrm{~cm}$. Print Room, Rijksmuseum, Amsterdam (artwork in the public domain).

Fig. 12 Dirk Jacobsz. Vellert, The Drunken Drummer, 1525, engraving, 9.2 x 5.8 cm. Kupferstichkabinett, Staatliche Kunstsammlungen, Dresden

Fig. 13 Dirk Jacobsz. Vellert, Bileam and the Ass, ca. 1522, ink drawing, 19.4 x $18.7 \mathrm{~cm}$. Herzog Anton Ulrich Museum, Braunschweig (artwork in the public domain).

Fig. 14 Hans Holbein the Younger, Luther as "Hercules germanicus," 1522, woodcut, 34.5 x 22.6 $\mathrm{cm}$ (From Heinrich Brennwald and Johannes Stumpf, Schweizer Chronik, Ms. A 2, before p. 150). Zentralbibliothek, Zürich (artwork in the public domain).

*All translations are the author's unless otherwise noted.

${ }^{1}$ This engraving is usually titled Three Peasants in Conversation (Bartsch 86), but based on their clothing, I doubt the two left-most figures are peasants.

${ }^{2}$ Hans-Ernst Mittig, Dürers Bauernsäule: Ein Monument des Widerspruchs (Frankfurt am Main: Fischer Verlag, 1984), esp. 32-47.

${ }^{3}$ Hans-Joachim Raupp, Bauernsatiren: Entstehung und Entwicklung des bäuerlichen Genres in der deutschen und niederländischen Kunst ca. 1470-1570 (Niederzier: Lukassen Verlag, 1986).

${ }^{4}$ Both Moxey and Stewart write about print designers in the so-called Little Masters circle, a group of artist in the generation following Dürer who were influenced by him. See Keith Moxey, Peasants, Wives and Warriors: Popular Imagery in the Reformation (Chicago: University of Chicago Press, 1989), and Alison Stewart, Before Bruegel: Sebald Beham and the Origins of Peasant Imagery (Aldershot, U.K.: Ashgate Press, 2008).

${ }^{5}$ Erwin Panofsky, “Dürers Stellung zur Antike," [1922] in Sinn und Deutung in der bildenden Kunst (Cologne: Dumont Verlag, 1996), 274-350; and Erwin Panofksy, The Life and Work of Albrecht Dürer (Princeton, N.J.: Princeton University Press, 1943).

${ }^{6}$ See the contribution by Michael Rohlmann, who recently emphasized Dürer's emancipation from Italian art in the course of painting the Rosenkranzfest. Michael Rohlmann, "Kunst in Nord und Süd - Bestellerinteressen der Frühen Neuzeit im Vergleich," review of Kunstpatronage in der Frühen Neuzeit: Studien zu Kunstmarkt, Künstlern und ihren Auftraggebern in Italien und im Heiligen Römischen Reich (15.-17. Jahrhundert), by Bernd Roeck, Zeitschrift für historische Forschung 27 (2000): 407-13. On the emerging German nationalism, see Larry Silver, "Germanic Patriotism in the Age of Dürer," in Dürer and His Culture: In Memory of Bob Scribner, 1941-1998, 
ed. Dagmar Eichberger and Charles Zika (Cambridge: Cambridge University Press, 1998), 38-68. With reference to Konrad Celtis, see the recent publication of Jörg Robert,Konrad Celtis und das Projekt der deutschen Dichtung: Studien zur humanistischen Konstitution von Poetik, Philosophie, Nation und Ich (Tübingen: Niemeyer Verlag, 2003), 345-439.

${ }^{7}$ See the studies by Panofsky named above and, as an introduction to Dürer's journeys to Venice, Ludwig Grote,Albrecht Dürer: Reisen nach Venedig (Munich: Prestel Verlag, 1998).

${ }^{8}$ Jan Bialostocki, Dürer and His Critics 1500-1971: Chapters in the History of Ideas (Baden-Baden: Koerner Verlag, 1986).

9 "Awch sind mir jr vill feind vnd machen mein ding in kirchen ab vnd wo sy es mügen bekumen. Noc schelten sy es vnd sagen, es sey nit antigisch art, dorum sey es nit gut." Hans Rupprich, Dürer: Schriftlicher Nachlaß (Berlin: Deutscher Verlag für Kunstwissenschaft, 1956), $1: 43-44$.

10 “... jch hab awch dy moler all geschtilt, dy do sagten, jm stechen wer jch gut, aber jm molen west jch nit mit farben um zw gen. Jtz spricht jder man, sy haben schoner farben nie gesehen.” Rupprich, Dürer: Schriftlicher Nachlaß, 1:55.

${ }^{11}$ Leonardo da Vinci, Traktat von der Malerei (Jena: Diederichs Verlag, 1925), 48-49. For an excellent analysis of aemulatio as a humanist practice, see Thomas Greene, The Light in Troy: Imitation and Discovery in Renaissance Poetry (New Haven, Conn.: Yale University Press, 1982). ${ }^{12}$ Sybille Ebert-Schifferer, ed., Natur und Antike in der Renaissance (Exhibition at Liebighaus in Frankfurt am Main, Germany, December 5 - March 2, 1986),400-402, no. 97.

${ }^{13}$ Christiane Kruse, "Ars latet arte sua: Zur Kunst des Kunstverbergens im Barock," in Animationen, Transgressionen: Das Kunstwerk als Lebewesen, eds. Ulrich Pfisterer and Anja Zimmermann (Berlin: Akademie-Verlag, 2005), 95-113.

${ }^{14}$ Plato, Symposium, trans. Seth Bernadette (Chicago: University of Chicago Press, 2001), 47 (217a).

${ }^{15}$ For the Silenic-Socratic poetics of images, see Jürgen Müller, Das Paradox als Bildform: Studien zur Ikonologie Pieter Bruegels d. Ä. (Munich: Fink Verlag, 1999). With regard to the Laocoön, see Jürgen Müller, "Holbein und Laokoon: Ein Beitrag zur gemalten Kunsttheorie Hans Holbeins d.J," in Hans Holbein und der Wandel in der Kunst des frühen 16. Jahrhunderts, ed. Bodo Brinkmann and Wolfgang Schmid (Turnhout: Brepols, 2005), 73-89. One early discussion of ironic structures in art is Irving Lavin, "Divine Inspiration in Caravaggio's Two St. Matthews," Art Bulletin 56 (1974): 59-81. Furthermore, attention should be drawn to David A. Levine, "The Roman Limekilns of the Bamboccianti," Art Bulletin 70 (1988): 569-89. Another important early publication on the theme is Reindert L. Falkenburg, " Alter Einoutus': Over de aard en herkomst van Pieter Aertsens stillevenconceptie," Nederlands Kunsthistorisch Jaarboek 40 (1989): 41-66. Finally, it must be said that all this research work is indebted to Erich Auerbach, who pointed to the ironic constitution of the "sermo humilis." See Erich Auerbach, Mimesis: Dargestellte Wirklichkeit in der abendländischen Literatur (Bern and Stuttgart: Franke Verlag, 1988).

${ }^{16}$ See Wolfgang G. Müller, "Ironie, Lüge, Simulation, Dissimulation und verwandte rhetorische Termini," in Zur Terminologie der Literaturwissenschaft: Akten des IX. Germanistischen Symposions der Deutschen Forschungsgemeinschaft Würzbug 1986, ed. Christian Wagenknecht (Stuttgart: Metzler Verlag, 1986), 189-208.

17 "The bagpipe is the fool's game/ he doesn't respect the harp/ he doesn't care for any good in the world/ besides his staff/ and pipe." Sebastian Brant, Das Narrenschiff [1494], ed. Joachim Knape (Stuttgart: Reclam Verlag, 2005), 284. 
${ }^{18}$ As an introduction, see Matthias Winner, "Zum Nachleben des Laokoon in der Renaissance," Jahrbuch der Berliner Museen, n.s. 16 (1974): 83-121. See also the concise discussion of Dürer's second journey to Venice and possibly Rome inFedja Anzelewsky, Albrecht Dürer: Das malerische Werk (Berlin: Deutscher Verlag für Kunstwissenschaft, 1991).

${ }^{19}$ On the classical theory of imitation, see W. G. Pigmann III, "Versions of Imitation in the Renaissance," Renaissance Quarterly 33 (1980): esp. 1-32. See also Klaus Irle, Der Ruhm der Bienen: Das Nachahmungsprinzip der italienischen Malerei von Raffael bis Rubens. (Münster and New York: Waxmann, 1997).

${ }^{20}$ On the practice of dissimulatio of borrowed motifs, see Ernst H. Gombrich,Zur Kunst der Renaissance, vol. 1 (Stuttgart: Klett-Cotta Verlag, 1985), 16162.

${ }^{21}$ For instance, Leon Battista Alberti, On Painting, trans. Cecil Grayson (London: Penguin Books, Ltd., 1991).

22 "Aber dorbey ist zw melden, das ein ferstendiger geübter künstner jn grober bewrischer gestalt sein grossen gwalt vnd kunst ertzeigen kan mer jn eim geringen ding dan mencher jn ein grossen werg." Rupprich, Dürer: Schriftlicher Nachlaß, 3:284.

${ }^{23}$ See Julius Held, Dürers Wirkung auf die niederländische Kunst seiner Zeit (The Hague: Nijhoff, 1931).

24 "Am sontag nach unsers Herrn auffarth tag lud mich meister Dietrich, glaßmahler zu Antorff, und mir zu lieb viel anderer leuth, nehmlich darunter Alexander, goldschmiedt, ein statthafft reicher mann; und wir hetten ein köstlich mahl, und man thet mir groß ehr." Rupprich, Dürer: Schriftlicher Nachlaß, 1:169.

25 "Jtem mehr hab ich geschenckt herr Jacob Panisio ein gutes gemahltes Veronicae angsicht, ein Eustachius, Melancholej und ein siczenden Hieronymum, S. Antonium, die 2 neuen Mariensbilder und den neuen bauren. So hab ich geschenckt sein schreiber, dem Erasmo, der mir die supplication gestellet hat, ein siczenden Hieronymum, die Melancoley, den Antonium, die 2 neuen Marienbildt, den bauern, vnd jch habe jhm auch 2 kleine Marienbildt geschickt, und das alles, das jch ihn geschenckt hab, ist werth 7 gulden." Rupprich, Dürer: Schriftlicher Nachlaß, 1:156-57.

${ }^{26}$ For this theme, see Larry Silver, "The Ill-Matched Pair by Quentin Massys," Studies in the History of Art 6 (1974): 4-23; and Alison Stewart, Unequal Lovers: A Study of Unequal Couples in Northern Art (New York: Abaris Books, 1977).

${ }^{27}$ Raupp, Bauernsatiren.

${ }^{28}$ Further examples in Raupp, Bauernsatiren, 48.

${ }^{29}$ There are no studies on Dirk Vellert's complete works, but several studies focus on particular aspects. On the artist as painter, see Ludwig Baldass, "Dirk Vellert als Tafelmaler," Belvedere 1 (1922): 162-67. As a graphic artist, see Henry Sayles Francis, "Dirk Vellert: Etcher," Bulletin of the Cleveland Museum of Art 25 (1938): 6-10. As designer of glass painting, see the forthcoming book by Ellen Konowitz, Images in Light and Line: the Stained Glass Designs and Prints of Dirk Vellert(Turnhout: Brepols, forthcoming, 2010).

${ }^{30}$ Numbers, 20:21-33.

${ }^{31}$ In his analysis of Pieter Aertsen, Reindert Falkenburg has referred in this context to the tradition of the paradoxical encomium, for which many examples can be found in antiquity and which has found its most prominent example in Erasmus's Praise of Folly. See Falkenburg, "'Alter Einoutus," and Reindert Falkenburg, "Pieter Aertsen, Rhyparographer," in Rhetoric-Rhétoriquers-Rederijkers, eds. J. Koopmans, M. Meadow, M. Spies (Amsterdam: Royal Netherlandish Academy of Arts and Sciences, 1995), 197-215. 
${ }^{32}$ See J. Müller, "Holbein und Laokoon."

${ }^{33}$ On the Laocoon reception in Italian art theory, see Salvatore Settis, Laocoonte: Fama e stile (Roma: Donzelli, 1999).

34 The statue was found on January 14, 1506, on the property of Felice de' Freddi near S. Maria Maggiore in Rome. For the rediscovery, see Francis Haskell and Nicholas Penny, Taste and the Antique: The Lure of Classical Sculpture, 1500-1900 (New Haven, Conn.: Yale University Press, 1981), 243-47.

${ }^{35}$ Hans Henrik Brummer, “The Statue Court in the Vatican Belvedere,"Acta Universitatis Stockholmiensis - Stockholm Studies in History of Art 20 (1970). See also, Leonard Barkan, Unearthing the Past: Archaeology and Aesthetics in the Making of Renaissance Culture (New Haven, Conn.: Yale University Press, 1999).

${ }^{36}$ On Tommaso Inghirami and an imperial rhetoric of the Church, see Luca D'Ascia, Erasmo e l'Umanesimo romano (Florence: Olschki, 1991). Also Luca D’Ascia, "Una 'Laudatio Ciceronis' inedita di Tommaso 'Fedra' Inghirami,” Rivista di letteratura italiana 5 (1987): 479-501.

37 "Of course!” Erasmus von Rotterdam, “Julius vor der verschlossenen Himmelstür: Ein Dialog," in Ausgewählte Schriften: Lateinisch/Deutsch, ed. Werner Welzig, vol. 5 (Darmstadt: Wissenschaftliche Buchgesellschaft, 1990), 13.

${ }^{38}$ Erasmus von Rotterdam, “Julius vor der verschlossenen Himmelstür," 11.

${ }^{39}$ For a comprehensive interpretation with bibliographical references see J. Müller, "Holbein und Laokoon."

${ }^{40}$ On the veneration of Hercules by the ancient Germans, see Publius Cornelius Tacitus, Agricola, Germania, Dialogus de Oratoribus, Die historischen Versuche, trans. Karl Büchner (Stuttgart: Alfred Kröner Verlag, 1985) 150-51.

${ }^{41}$ On the perceptibility of the stylistic difference between "welsch" and "deutsch," see Michael Baxandall, Die Kunst der Bildschnitzer: Tilman Riemenschneider, Veit Stoß und ihre Zeitgenossen (Munich: Beck Verlag, 1984), 144-51.

${ }^{42}$ Martin Luther, Aufbruch zur Reformation, ed. Karin Bornkamm and Gerhard Ebeling (Frankfurt am Main and Leipzig: Insel Verlag, 1995), 182.

${ }^{43}$ For the exploitation of the Laocoön, see J. Müller, "Holbein und Laokoon."73-89. On the figure of Pope Julius II, Erasmus's polemical dialogue is still the classic work. See Erasmus von Rotterdam, "Julius vor der verschlossenen Himmelstür."

${ }^{44}$ On the modernity of the Reformation,see Werner Hofmann, introduction to Luther und die Folgen für die Kunst (Exhibition at Hamburger Kunsthalle, Germany, November 11, 1983 - January 8, 1984), ed. Werner Hofmann (Munich: Prestel Verlag, 1983), xvii-xix.

\section{Bibliography}

Alberti, LeonBattista.On Painting. Translated by Cecil Grayson. London: Penguin Books, Ltd., 1991.

Anzelewsky, Fedja. Albrecht Dürer: Das malerische Werk. Berlin: Deutscher Verlag für Kunstwissenschaft, 1991.

Auerbach, Erich. Mimesis: Dargestellte Wirklichkeit in der abendländischen Literatur. Bernand Stuttgart: Franke Verlag, 1988. 
Barkan, Leonard. Unearthing the Past: Archaeology and Aesthetics in the Making of Renaissance Culture. New Haven, Conn.: Yale University Press, 1999.

Baldass, Ludwig.“Dirk Vellert als Tafelmaler,” Belvedere 1 (1922): 162-67.

Baxandall, Michael. Die Kunst der Bildschnitzer: Tilman Riemenschneider, Veit Stoß und ihre Zeitgenossen. Munich: Beck Verlag, 1984.

Bialostocki, Jan. Dürer and His Critics 1500-1971: Chapters in the History of Ideas. Baden-Baden: Koerner Verlag, 1986.

Brant, Sebastian. Das Narrenschiff [1494]. Edited by Joachim Knape. Stuttgart: Reclam Verlag, 2005.

Brummer, Hans Henrik. The Statue Court in the Vatican Belvedere. Stockholm: Almqvist \& Wiksell, 1970.

D’Ascia, Luca. “Una 'Laudatio Ciceronis' inedita di Tommaso 'Fedra' Inghirami,” Rivista di letteratura italiana 5 (1987): 479-501.

D’Ascia, Luca. Erasmo e l’Umanesimo romano. Florence: Olschki, 1991.

Ebert-Schifferer, Sybille, ed. Natur und Antike in der Renaissance (Exhibition at Liebighaus in Frankfurt am Main, Germany, December 5 - March 2, 1986). Frankfurt am Main: Liebighaus Museum Alter Plastik, 1985.

Falkenburg, Reindert L. “'Alter Einoutus:' Over de aard en herkomst van Pieter Aertsens stillevenconceptie.” Nederlands Kunsthistorisch Jaarboek40 (1989): 41-66.

. "Pieter Aertsen, Rhyparographer." In Rhetoric-Rhétoriquers-Rederijkers, edited by J. Koopmans, M. Meadow, and M. Spies, 197-215. Amsterdam: Royal Netherlandish Academy of Arts and Sciences, 1995.

Francis, Henry Sayles. “Dirk Vellert: Etcher." Bulletin of the Cleveland Museum of Art25 (1938): 6-10.

Gombrich,Ernst H. Zur Kunst der Renaissance. Vol. 1. Stuttgart: Klett-Cotta Verlag, 1985.

Greene, Thomas. The Light in Troy: Imitation and Discovery in Renaissance Poetry. New Haven, Conn.: Yale University Press, 1982.

Grote, Ludwig.Albrecht Dürer: Reisen nach Venedig. Munich: Prestel Verlag, 1998.

Haskell, Francis, and Nicholas Penny. Taste and the Antique: The Lure of Classical Sculpture, 
1500-1900. New Haven, Conn.: Yale University Press, 1981.

Held, Julius. Dürers Wirkung auf die niederländische Kunst seiner Zeit. The Hague: Nijhoff, 1931.

Hofmann, Werner. Introduction to Luther und die Folgen für die Kunst (Exhibition at Hamburger Kunsthalle, Germany, November 11, 1983 - January 8, 1984). Edited by Werner Hofmann. Munich: Prestel Verlag, 1983.

Irle, Klaus. Der Ruhm der Bienen: Das Nachahmungsprinzip der italienischen Malerei von Raffael bis Rubens. Münster and New York: Waxmann, 1997.

Konowitz, Ellen. Images in Light and Line: The Stained Glass Designs and Prints of Dirk Vellert. Turnhout: Brepols [forthcoming, 2010].

Kruse, Christiane. "Ars latet arte sua: Zur Kunst des Kunstverbergens im Barock." In Animationen, Transgressionen: Das Kunstwerk als Lebewesen, edited by Ulrich Pfisterer and Anja Zimmermann, 95-113. Berlin: Akademie-Verlag, 2005.

Lavin, Irving. “Divine Inspiration in Caravaggio’s Two St. Matthews.” Art Bulletin56 (1974): 59-81.

Leonardo da Vinci. Traktat von der Malerei. Jena: Diederichs Verlag, 1925.

Levine, David A. “The Roman Limekilns of the Bamboccianti.” Art Bulletin70 (1988): 569-89.

Luther, Martin. Aufbruch zur Reformation. Edited by Karin Bornkamm and Gerhard Ebeling. Frankfurt am Main and Leipzig: Insel Verlag, 1995.

Mittig, Hans-Ernst. Dürers Bauernsäule: Ein Monument des Widerspruchs. Frankfurt am Main: Fischer Verlag, 1984.

Moxey, Keith. Peasants, Wives and Warriors: Popular Imagery in the Reformation, Chicago: University of Chicago Press, 1989.

Müller, Jürgen. Das Paradox als Bildform: Studien zur Ikonologie Pieter Bruegels d. Ä. Munich: Fink Verlag, 1999.

Müller, Jürgen. "Holbein und Laokoon: Ein Beitrag zur gemalten Kunsttheorie Hans Holbeins d.J." In Hans Holbein und der Wandel in der Kunst des frühen 16. Jahrhunderts, edited by Bodo Brinkmann and Wolfgang Schmid, 73-89. Turnhout: Brepols, 2005.

Müller, Wolfgang G. "Ironie, Lüge, Simulation, Dissimulation und verwandte rhetorische Termini." In Zur Terminologie der Literaturwissenschaft: Akten des IX. Germanistischen Symposions der Deutschen Forschungsgemeinschaft Würzbug 1986, edited by Christian Wagenknecht, 189-208. Stuttgart: Metzler Verlag, 1986. 
Panofsky, Erwin. "Dürers Stellung zur Antike" [1922]. In Sinn und Deutung in der bildenden Kunst, 274-350. Cologne: Dumont Verlag, 1996.

Panofksy, Erwin. The Life and Work of Albrecht Dürer. Princeton, N.J.: Princeton University Press, 1943.

Pigmann III, W. G. "Versions of Imitation in the Renaissance," Renaissance Quarterly 33, (1980): $1-33$.

Plato, Symposium. Translated by Seth Bernadette. Chicago: University of Chicago Press, 2001.

Raupp, Hans-Joachim. Bauernsatiren: Entstehung und Entwicklung des bäuerlichen Genres in der deutschen und niederländischen Kunst ca. 1470-1570. Niederzier: Lukassen Verlag, 1986.

Robert, Jörg. Konrad Celtis und das Projekt der deutschen Dichtung: Studien zur humanistischen Konstitution von Poetik, Philosophie, Nation und Ich. Tübingen: Niemeyer Verlag, 2003.

Rohlmann, Michael. "Kunst in Nord und Süd - Bestellerinteressen der Frühen Neuzeit im Vergleich." Review of Kunstpatronage in der Frühen Neuzeit: Studien zu Kunstmarkt, Künstlern und ihren Auftraggebern in Italien und im Heiligen Römischen Reich (15.-17. Jahrhundert), by Bernd Roeck. Zeitschrift für historische Forschung 27 (2000): 407-13.

Rotterdam, Erasmus von. "Julius vor der verschlossenen Himmelstür: Ein Dialog" In Ausgewählte Schriften: Lateinisch/Deutsch, edited by Werner Welzig. Vol. 5. Darmstadt: Wissenschaftliche Buchgesellschaft, 1990.

Rupprich, Hans. Dürer: Schriftlicher Nachlaß. Vols. 1-5. Berlin: Deutscher Verlag für Kunstwissenschaft, 1956-69.

Settis, Salvatore. Laocoonte: Fama e stile. Rome: Donzelli, 1999.

Silver, Larry. "Germanic Patriotism in the Age of Dürer." In Dürer and His Culture: In Memory of Bob Scribner, 1941-1998, edited by Dagmar Eichberger and Charles Zika, 38-68. Cambridge: Cambridge University Press, 1998.

Silver, Larry. "The Ill-Matched Pair by Quentin Massys." Studies in the History of Art 6 (1974): $4-23$.

Stewart, Alison. Unequal Lovers: A Study of Unequal Couples in Northern Art. New York: Abaris Books, 1977.

Stewart, Alison. Before Bruegel: Sebald Beham and the Origins of Peasant Imagery, Aldershot, U.K.: Ashgate Press, 2008. 
Tacitus, Publius Cornelius. Agricola, Germania, Dialogus de Oratoribus, Die historischen Versuche. Translated by Karl Büchner. Stuttgart: Alfred Kröner Verlag, 1985.

Winner, Matthias. “Zum Nachleben des Laokoon in der Renaissance," Jahrbuch der Berliner Museen n.s. 16 (1974): 83-121.

Recommended Citation:

Jürgen Müller, "Albrecht Dürer's Peasant Engravings: A Different Laocoön, or the Birth of Aesthetic Subversion in the Spirit of the Reformation," JHNA 3:1 (Winter 2011), D0I: 10.5092/jhna.2011.3.1.2 